\title{
PENGARUH TERAPI SPIRITUAL EMOTIONAL FREEDOM TECHNIQUE (SEFT) TERHADAP PENURUNAN TINGKAT KECEMASAN PADA LANSIA SELAMA MASA PANDEMI COVID-19
}

Sakiyan ${ }^{1}$,Mugihartadi ${ }^{2}$

\author{
Dosen STIKES Serulingmas Cilacap ${ }^{1}$ \\ Dosen Akademi Keperawatan Pemkab Purworejo ${ }^{2}$ \\ E-mail : sakiyankhahanan175@gmail.com
}

\begin{abstract}
ABSTRAK
Latar Belakang: Angka kematian akibat virus Covid-19 berdasarkan World Health Organization (WHO) pertanggal 19 April 2020 sebanyak 152.551 jiwa (WHO, 2020). Menurut data Kemenkes, RI presentase terkonfirmasi positif Covid-19 tanggal 27 Mei 2020 sebanyak 23.851 kasus, dan meninggal dunia sebanyak 1.473 kasus. Lanjut usia sering mengalami gangguan psikologis seperti stres, depresi dan anxiety terutama dalam menghadapi wabah Covid-19 ini karena banyaknya informasi tentang penduduk Indonesia yang terkonfirmasi positif dan menyebabkan kematian semakin menambah tingkat kecemasan. Upaya dalam mengatasi kecemasan yang terjadi pada lanjut usia dapat dilakukan dengan relaksasi spiritual SEFT. Tujuan: Menganalisis pengaruh terapi Spiritual Emotional Freedom Technique (SEFT) terhadap penurunan tingkat kecemasan pada lansia di Desa Grantung, Kecamatan Bayan, Kabupaten Purworejo. Metode: Jenis penelitian ini menggunakan desain penelitian pre experimental design dengan rancangan one group pretest-posttest. Teknik pengambilan sampel menggunakan total sampling dengan jumlah sampel 79 lansia di di Desa Grantung, Kecamatan Bayan, Kabupaten Purworejo. Teknik analisa data menggunakan Wilcoxon Signed Rank Test. Instrumen penelitian menggunakan lembar kuesioner HARS dan SOP terapi SEFT. Hasil : Hasil penelitian menunjukkan tingkat kecemasan lansia sebelum diberikan terapi SEFT sebagian besar dengan kategori kecemasan sedang dan setelah diberikan terapi SEFT sebagian besar tingkat kecemasan lansia menurun menjadi kategori ringan. Kesimpulan : Ada pengaruh terapi SEFT terhadap tingkat kecemasan pada lansia selama masa pandemic Covid-19 di Desa Grantung dengan nilai $p=0.000$ ( $p$ value < 0,05). Rekomendasi untuk lansia sebaiknya menerapkan terapi SEFT secara mandiri untuk mengatasi masalah kecemasan selama menghadapi masa pandemic covid-19.
\end{abstract}

Kata kunci : Terapi SEFT, Kecemasan, Pandemi Covid-19

\begin{abstract}
Background: The death rate due to the Covid-19 virus based on the World Health Organization (WHO) dated April 19, 2020 was 152,551 people (WHO, 2020). According to data from the Ministry of Health, the percentage of confirmed positive Covid-19 on 27 May 2020 was 23,851 cases, and 1,473 cases died. Elderly people often experience psychological disorders such as stress, depression and anxiety, especially in the face of the Covid-19 outbreak because a lot of information about the Indonesian population has been confirmed positive and causes death to increase the level of anxiety. Efforts in overcoming anxiety that occurs in the elderly can be done with SEFT spiritual relaxation. Objective: To analyze the effect of Spiritual Emotional Freedom Technique (SEFT) therapy on reducing anxiety levels in the elderly in Grantung Village, Bayan District, Purworejo Regency. Methods: This type of research used a pre-experimental research design with one group pretestposttest design. The sampling technique used total sampling with a sample size of 79 elderly in Grantung Village, Bayan District, Purworejo Regency. The data analysis technique used the Wilcoxon
\end{abstract}


Signed Rank Test. The research instrument used HARS questionnaire sheet and SEFT therapy SOP. Results: The results showed that most of the anxiety levels of the elderly before being given SEFT therapy were in the moderate category of anxiety and after being given SEFT therapy, most of the anxiety levels in the elderly decreased to the mild category. Conclusion: There is an effect of SEFT therapy on the level of anxiety in the elderly during the Covid-19 pandemic in Grantung Village with a value of $p=0.000$ ( $p$ value <0.05). Recommendations:for the elderly should apply SEFT therapy independently to deal with anxiety problems during the pandemic Covid-19.

\section{Keywords: SEFT Therapy, Anxiety, Pandemic Covid-19}

\section{Latar Belakang}

Virus corona (Covid-19) semenjak bulan Januari 2020 telah ditetapkan oleh WHO sebagai pandemi karena telah menginfeksi hampir seluruh Negara di dunia seperti Amerika, Italia, Jerman, Belanda, Ekwador, Turki, Iran, Wilayah Asia termasuk Singapore, Philipina, Malaysia sampai ke Indonesia (WHO, 2020). Virus ini sangat berbahaya karena disamping penyebarannya yang sangat cepat bahkan dapat menyebabkan kematian.

Angka kematian akibat virus Covid-19 berdasarkan data World Health Organization (WHO) pertanggal 19 April 2020 sebanyak 152.551 jiwa (WHO, 2020). Berdasarkan data Kementerian Kesehatan RI, tahun 2020 Covid19 pertama dilaporkan di Indonesia pada tanggal 2 Maret 2020 sejumlah dua kasus. Tingkat mortalitas Covid-19 di Indonesia sebesar 8,9\%, angka ini merupakan yang tertinggi di Asia Tenggara. (Kemenkes RI, 2020).

Menurut data Kemenkes, RI presentase terkonfirmasi positif Covid-19 terupdate tanggal 27 Mei 2020 dilaporkan sebanyak 23.851 kasus, dinyatakan sembuh sebanyak 6.057 kasus, dan yang meninggal dunia sebanyak 1.473 kasus. Sementara itu di Provinsi Jawa Tengah dilaporkan terdapat 1326 kasus positif Covid-19, Rata-rata jumlah kasus positif per hari dalam 14 hari terakhir sebanyak 21,64\%, dan terdapat 142 kematian akibat Covid-19 atau sebanyak 6,6\% (Kemenkes, RI, 2020).

Pemerintah Kabupaten Purworejo sendiri telah menyatakan status Tanggap Darurat Covid-19 bagi wilayahnya mulai tanggal 28 Maret 2020 hingga 29 Mei 2020. Berdasarkan data yang diunggah diwebsite resmi Pemerintah Provinsi Jawa Tengah pada tanggal 22 Mei 2020, dari 566 pasien positif covid-19 yang dirawat di RS, 59 orang diantaranya dirawat di RSUD dr Tjitrowardojo Purworejo.

Pandemi Covid-19 tidak hanya mengancam anak-anak dan dewasa, namun juga dapat menginfeksi lansia. Hurlock (1980) menyatakan usia tua yaitu sebuah periode seseorang yang telah beranjak dari periode yang produktif. Pada setiap periode lanjut usia, gangguan psikologis sering terganggu seperti stres, depresi dan termasuk juga anxiety (Ifdil, B Khairul, 2015;Taufik, T., \& Ifdil, I. 2013). Dalam hal ini lansia mengalami kecemasan terhadap adanya wabah Covid-19. Informasi tentang banyaknya penduduk Indonesia yang terkonfirmasi positif bahkan sampai menyebabkan kematian semakin menambah tingkat kecemasan.

Menurut Fitria, (2020), lansia sangat 
rentan mengalami gangguan pada kesehatan fisik maupun jiwa. Kondisi psikologis yang dialami oleh lansia adalah rasa anxiety akan tertular virus ini. Dampak yang timbul ketika harus menghadapi situasi banyaknya wabah dapat menimbulkan stres. Kebijakan Lockdown yang dikeluarkan pemerintah menyebabkan terjadinya perubahan signifikan yang terjadi dalam menjalani aktivitas keseharian dan ketika melihat serta mengetahui data statistik penyebaran virus dan jumlah pasien positif hingga jumlah korban meninggal dunia dapat menyebabkan tingkat kecemasan bertambah (Aufar, 2020).

Hasil penelitian Huang \& Zhao, (2020) dalam jurnal Psychiatry Research mensurvei lebih dari 7.200 pria dan wanita di China selama lockdown yang diberlakukan pada bulan Februari 20020. Lebih dari sepertiga responden ditemukan menderita "Gangguan Kecemasan Umum" terkait-COVID, sementara sekitar seperlimanya merasakan adanya tanda-tanda depresi. Sedangkan lebih dari 18\% mengatakan adanya aktivitas kesulitan untuk tidur.

Upaya unuk mengatasi kecemasan yang terjadi pada lanjut usia dapat pula dilakukan dengan relaksasi dan distraksi (Keliat, 2013). Relaksasi adalah suatu proses untuk melepaskan ketegangan yang ada secara sengaja atau disadari. Selain relaksasi penderita kecemasan juga dapat melakukan Spiritual Emotional Freedom Technique (SEFT) (Zainuddin, 2012).

\section{Spiritual Emotional Freedom Technique} (SEFT) merupakan teknik terapi yang menggabungkan sistem energi tubuh (energy medicine) dan terapi spiritual yang digunakan untuk mengatasi masalah emosional dan fisik, yaitu dengan melakukan ketukan ringan (tapping) di titik-titik tertentu pada tubuh (Anwar, 2010). SEFT bisa menjadi salah satu metode yang berdasarkan mindfulness untuk menurunkan tingkat stress pada individu dengan berbagai masalah psikologis (Esch, Fricchione, Joos, \& Teut, 2013).

Kelebihan teknik ini yaitu cara yang digunakan lebih aman, lebih mudah lebih cepat dan sederhana, karena SEFT hanya menggunakan ketukan ringan (tapping). Terapi SEFT bisa dilakukan oleh siapa saja dan tidak perlu mengeluarkan biaya yang besar. Salah satu hal yang membuat terapi ini berbeda adalah karna terapi ini memiliki kekuatan penyembuhan yang super dahsyat yaitu doa (Zainuddin, 2012).

Beberapa penelitian telah menunjukan bahwa teknik SEFT dapat digunakan untuk menurunkan tingkat kecemasan, seperti penelitian yang dilakukan oleh Chodijah, (2020) menunjukan bahwa dengan menggunakan tahapan yang tepat dari terapi SEFT, tingkat kecemasan klien menurun, sehingga dapat dianjurkan untuk dapat digunakan secara lebih luas kepada masyarakkat yang mengalami kecemasan akibat pandemi virus Covid-19. Sejalan dengan penelitian yang dilakukan oleh Brahmantia, (2018) dengan judul Pengaruh Spiritual Emotional Freedom Technique (SEFT) Terhadap Penurunan Nyeri Dan Kecemasan Pada Pasien Pasca Bedah Transurethral Resection Prostate (TURP) di RSUD dr. Soekardjo Kota Tasikmalaya menunjukan ada pengaruh SEFT terhadap penurunan nyeri dan kecemasan pada pasien 
pasca bedah TURP dimana rata-rata nilai cemas sebelum diberikan terapi SEFT pada kelompok intervensi 19,59 dan sesudah diberikan intervensi menurun menjadi 11,86.

Berdasarkan survei pendahuluan yang telah dilakukan di Wilayah Puskesmas Bayan khususnya Desa Grantung, Kabupaten Purworejo terdapat sejumlah 358 Lansia pada Bulan Mei 2020 dan terdapat 28 kasus yang terkonfirmasi positif Covid-19. Selain itu penulis juga melakukan melakukan wawancara dengan tiga orang lansia di Desa Grantung didapatkan data bahwa 2 orang lansia mengatakan panik, tidak bisa tidur dan takut lama kelamaan bisa terinfeksi virus corona, 1 orang mengatakan mengalami tingkat kecemasan yang sedang karena sudah pasrah kepada Tuhan terkait wabah virus corona ini. Penulis juga melakukan wawancara dengan tenaga kesehatan yang bertugas di Desa Grantung bahwa selama ini belum pernah mengaplikasikan manajemen stress dengan terapi spiritual emotional freedom tehnique (SEFT).

Berdasarkan fenomena di atas, peneliti tertarik untuk meneliti tentang "Pengaruh Terapi Spiritual Emotional Freedom Technique (SEFT) Terhadap Penurunan Tingkat Kecemasan Pada Lansia Selama Masa Pandemi Covid-19".

\section{Metode}

Metode penelitian yang digunakan dalam penelitian ini adalah metode kuantitatif dengan desain penelitian pre experimental design dengan rancangan one group pretest-posttest. Tempat penelitian dan waktu penelitian dilakukan di Desa Grantung Kecamatan Bayan, Kabupaten Purworejo pada bulan Juni-Juli Tahun 2020. Populasi dalam penelitian ini adalah seluruh lansia di Desa Grantung Kecamatan Bayan, sejumlah 358 lansia. Sampel dalam penelitian ini berjumlah 79 lansia yang diambil dengan teknik simple random sampling.

\section{Hasil \\ Analisa Univariat}

\section{1) Karakteristik Responden}

Tabel 1

Distribusi Frekuensi KarakteristikResponen di Desa Grantung, Kecamatan Bayan,

\begin{tabular}{|c|c|c|}
\hline $\begin{array}{l}\text { Karakteristik } \\
\text { responden }\end{array}$ & F (n) & $\mathbf{P}(\%)$ \\
\hline \multicolumn{3}{|l|}{ Umur } \\
\hline $\begin{array}{l}\text { 60-70 Tahun } \\
\text { 71-80 Tahun }\end{array}$ & $\begin{array}{l}36 \\
43\end{array}$ & $\begin{array}{l}45.6 \\
54.4\end{array}$ \\
\hline $\begin{array}{l}\text { Jenis kelamin } \\
\text { Laki-laki } \\
\text { Perempuan }\end{array}$ & $\begin{array}{l}35 \\
44\end{array}$ & $\begin{array}{l}44.3 \\
55.7\end{array}$ \\
\hline \multicolumn{3}{|l|}{ Pendidikan } \\
\hline Tidak Sekolah & 9 & 11.4 \\
\hline SD & 29 & 36.7 \\
\hline SMP & 17 & 21.5 \\
\hline SMA & 19 & 24.1 \\
\hline D1 & 2 & 2.5 \\
\hline $\mathrm{D} 3 / \mathrm{S} 1$ & 3 & 3.8 \\
\hline Total & 79 & 100,0 \\
\hline
\end{tabular}

Sumber: Data Primer (2020)

Hasil analisis pada tabel 1 dapat dilihat bahwa sebagian besar lansia berusia 71-80 tahun yaitu 43 responden (54.4\%), tingkat pendidikan sebagian besar responden memiliki riwayat pendidikan SD yaitu sebanyak 29 responden (36.7\%). Sedangkan untuk karakteristik jenis kelamin sebagian besar lansia memiliki jenis kelamin perempuan yaitu sebanyak 44 responden $(55.7 \%)$. 
2) Tingkat Kecemasan Lansia Sebelum Diberikan Terapi SEFT

Tabel 2

Distribusi Tingkat Kecemasan Lansia Sebelum Diberikan Terapi SEFT

\begin{tabular}{ccc}
\multicolumn{3}{c}{$(\mathrm{N}=79)$} \\
\hline Kategori & $\mathbf{F ~}(\mathbf{n})$ & $\mathbf{P}(\boldsymbol{\%})$ \\
\hline Berat & 8 & 10.1 \\
Ringan & 22 & 27.8 \\
Sedang & 49 & 62.0 \\
\hline Total & 79 & 100,0 \\
\hline
\end{tabular}

Sumber: Data Primer (2020)

Tabel 2 menunjukan sebagian besar lansia sebelum diberikan terapi SEFT memiliki tingkat kecemasan lansia dalam menghadapi masa pandemi kategori sedang yaitu sebanyak 49 responden $(62 \%)$, responden yang memiliki tingkat kecemasan ringan sebanyak 22 responden (27.8\%) dan terendah adalah responden dengan tingkat kecemasan berat dalam menghadapi masa pandemi sebanyak 8 responden $(10.1 \%)$.
3) Tingkat Kecemasan Lansia Setelah Diberikan Terapi SEFT

Tabel 3

Tingkat Kecemasan Lansia Setelah Diberikan Terapi SEFT ( $\mathrm{N}=79)$

\begin{tabular}{|c|c|c|}
\hline Kategori & $\begin{array}{l}\mathbf{F} \\
(\mathbf{n})\end{array}$ & Persentase (\%) \\
\hline Ringan & 53 & 67.1 \\
\hline Sedang & 6 & 7.6 \\
\hline $\begin{array}{r}\text { Tidak ada } \\
\text { kecemasan }\end{array}$ & 20 & 25.3 \\
\hline Total & 79 & 100,0 \\
\hline
\end{tabular}

sebagian besar tingkat kecemasan lansia menghadapi masa pandemic covid-19 setelah diberikan terapi SEFT dengan kategori ringan yaitu sebanyak 53 responden $(67.1 \%)$, dan terendah adalah responden yang memiliki tingkat kecemasan sedang setelah diberikan terapi SEFT yaitu sebanyak 6 responden $(7.6 \%)$.

\section{Analisa Bivariat}

\section{Uji Wilcoxon Signed Rank Test}

Tabel 4

Hasil Uji Wilcoxon Pengaruh terapi spiritual emotional freedom technique (SEFT) terhadap penurunan tingkat kecemasan pada lansia selama masa pandemic Covid-19 di Desa Grantung, Kecamatan Bayan, Kabupaten Purworejo $(\mathrm{N}=79)$

\begin{tabular}{|c|c|c|c|c|c|c|c|c|c|c|c|}
\hline \multirow[t]{2}{*}{ Terapi SEFT } & \multicolumn{4}{|c|}{ Tingkat Kecemasan } & \multirow[b]{2}{*}{$\begin{array}{l}\text { Kecem } \\
\text { asan } \\
\text { Sedang }\end{array}$} & \multirow[b]{2}{*}{$\%$} & \multirow[b]{2}{*}{$\begin{array}{l}\text { Kecemas } \\
\text { an Berat }\end{array}$} & \multirow[b]{2}{*}{$\%$} & \multirow[t]{2}{*}{ Jumlah } & \multirow[t]{2}{*}{$\mathrm{Z}$} & \multirow[t]{2}{*}{$\mathrm{P}$} \\
\hline & $\begin{array}{l}\text { Tidak } \\
\text { ada } \\
\text { kecem } \\
\text { asan }\end{array}$ & $\%$ & $\begin{array}{l}\text { Kecem } \\
\text { asan } \\
\text { Ringan }\end{array}$ & $\%$ & & & & & & & \\
\hline $\begin{array}{c}\text { Sebelum } \\
\text { diberikan } \\
\text { terapi SEFT }\end{array}$ & 0 & 0 & 22 & 27.8 & 49 & 62.0 & 8 & $\begin{array}{c}10 . \\
1\end{array}$ & 79 & -7.593 & 0,000 \\
\hline $\begin{array}{c}\text { Setelah } \\
\text { diberikan } \\
\text { terapi SEFT }\end{array}$ & 20 & 25.3 & 53 & 67.1 & 6 & 7.6 & 0 & 0 & 79 & & \\
\hline Jumlah & 20 & 12.7 & 75 & 47.5 & 55 & 34.8 & 8 & 5.1 & 158 & & \\
\hline
\end{tabular}

Sumber : Data primer, (2020).

Dari tabel 5 dapat dapat dilihat diberikan terapi SEFT sebagian besar tingkat kecemasan lansia sebelum dengan kategori sedang sebanyak 49 
responden $(62 \%)$ dan setelah diberikan terapi SEFT sebagian besar tingkat kecemasan lansia dengan kategori ringan sebanyak 53 responden (67.1\%).

Setelah melalui uji nonparametrik (Wilcoxon) didapatkan nilai $p=0.000(p$ value < 0,05), hal ini menunjukan adanya pengaruh terapi SEFT terhadap tingkat kecemasan pada lansia selama masa pandemic Covid-19 di Desa

\section{Pembahasan}

\section{Karakteristik responden}

Hasil penelitian menunjukan bahwa sebagian besar responden lansia berusia 71-80 tahun sebanyak $54.4 \%$. Responden dalam penelitian ini mayoritas adalah orang lanjut usia kategori tua dimana sesuai dengan klasifikasi lansia menurut WHO (2018) manusia usia lanjut terdiri atas usia pertengahan (middle age) kelompok usia 45-59 tahun, usia lanjut (elderly) kelompok usia $60-70$ tahun, usia lanjut tua (old) kelompok usia antara 75 - 90 tahun, usia sangat tua (very old) kelompok usia diatas 90 tahun (WHO, 2018).

Karakteristik jenis kelamin sebagian besar responden memiliki riwayat pendidikan SD yaitu sebanyak 29 responden (36.7\%), dan responden dengan riwayat pendidikan DI sebanyak 2 responden $(2.5 \%)$.

Karakteristik berdasarkan tingkat pendidikan menunjukan sebagian besar lansia memiliki jenis kelamin perempuan yaitu sebanyak 44 responden (55.7\%),
Grantung Kecamatan Bayan, Kabupaten Purworejo nilai Z score $-7.593>\mathrm{Z}$ score table dimana $\mathrm{Z}$ table dengan tingkat alpha 0,05 adalah -1,65 yang berarti yang berarti ada perbedaan yang signifikan antara tingkat kecemasan lansia sebelum diberikan terapi SEFT dengan tingkat kecemasan lansia setelah diberikan terapi

dan lansia laki-laki sebanyak 35 responden (44.3\%). Hasil penelitian menunjukan sebagian besar lansia memiliki jenis kelamin perempuan yaitu sebanyak 44 responden $(55.7 \%)$, dan lansia laki-laki sebanyak 35 responden $(44.3 \%)$. Jenis kelamin perempuan lebih sensitive dan memiliki emosi yang lebih peka dibandingkan dengan laki-laki disebabkan karena adanya pengaruh factor hormonal yang menurun seperti estrogen dan progesteron terutama pada pada lansia perempuan yang telah mengalami menopause. Oleh karena itu perempuan lebih cemas akan ketidakmampuannya menghadapi proses menua (aging process).

Sejalan dengan pendapat Mui (2012) prevalensi tingkat kecemasan pada lansia perempuan lebih banyak dibandingkan laki-laki disebabkan oleh perbedaan siklus hidup dan struktur sosial yang sering menempatkan perempuan sebagai subordinat lelaki. Perempuan lebih banyak menderita kecemasan karena adanya karakteristik khas perempuan seperti siklus reproduksi, menopause, 
menurunnya kadar esterogen. Perempuan lebih mudah merasakan perasaan bersalah, cemas, peningkatan bahkan penurunan nafsu makan dan gangguan tidur.

\section{Tingkat Kecemasan Lansia Sebelum} Diberikan Terapi SEFT

Berdasarkan hasil penelitian menunjukan sebagian besar lansia sebelum diberikan terapi SEFT memiliki tingkat kecemasan sedang yaitu sebanyak 49 responden (62\%), dan responden dengan tingkat kecemasan berat menghadapi masa pandemi sebanyak 8 responden $(10.1 \%)$. Hal ini menunjukan bahwa pada masa pandemi covid-19 mayoritas lansia mengalami kecemasan sedang yang disebabkan karena munculnya pikiran-pikiran negatif terutama dengan adanya berita dan informasi yang menyeramkan terkait prevalensi positif covid 19 dan kematian akibat infeksi virus ini yang semakin hari semakin meningkat tajam. Selain itu terjadi ketidakstabilan dalam hal ekonomi, penurunan penghasilan, kesulitan mencari lapangan pekerjaan akibat kebijakan lockdown yang ditetapkan pemerintah sebagai upaya pengendalian penyebaran covid-19. Adaptasi kebiasaan baru yang harus dihadapi sehari-hari tanpa adanya persiapan yang menyebabkan terjadi peningkatan kewaspadaan terutama lansia dan keluarga.

Pada lansia di Desa Grantung, Kec. Bayan, Kabupaten Purworejo mengalami kecemasan sedang dengan tanda dan gejala antara lain: gugup, tegang, berusaha menghindar, berdebar-debar, tubuh yang gemetaran, pikiran kacau, kesulitan fokus, sulit tidur, mudah tersinggung, muncul keringat dingin dan perasaan tidak tenang dan atas ancaman tertular Covid-19 ataupun mengalami kegagalan usaha dan menanggung kerugian baik moril maupun materiil di masa pandemi Covid-19.

Hal ini sesuai dengan Hawari (2011) kecemasan dapat muncul dalam diri individu dikarenakan adanya peningkatan kewaspadaan diri akan adanya bahaya yang mengancam. Stuart (2012) menambahkan bahwa faktor yang menyebabkan tingginya angka kecemasan adalah beratnya beban yang sedang dihadapi oleh seorang individu terutama lansia seperti dalam menghadapi wabah corona ini yang menimulkan ketakutan akan tertular dan menularkan virus dan dapat virus pada orang yang dicintai.

Menurut penelitian Purqoti (2020) banyak keluarga yang merasa cemas dan merasa semakin tertekan di masa pandemi yang muncul karena rasa khawatir akan sesuatu yang belum terjadi. Selama melakukan social distancing dalam keluarga muncul perilaku yang berlebih yaitu pembatasan sosial yang dilakukan dengan sesama anggota keluarga yang lain yang tinggal serumah karena diantara keluarga belum tentu semuanya sehat dan terbebas dari virus mengakibatkan kecemasan. Dengan adanya hal ini ruang gerak lansia semakin terbatas dikarenakan 
adanya kehawatiran bahaya covid 19 dan berbagai danpak buruk yang disebarkan melalui media masa ditambah dengan berita terkait covid 19 yang belum jelas kebenaranya dapat meningkatkan rasa cemas bagi lansia dan keluarga.

Hasil ini didukung penelitian yang dilakukan tingkat kecemasan responden paling banyak dalam kategori kecemasan sedang sebanyak 77 orang $(48,1 \%)$, Hasil ini menunjukkan keluarga yang memiliki anggota keluarga dengan usia lanjut memiliki kecemasan akan berbagai penyebaran berita hoax, penyebaran yang tidak sesuai dan semakin merajalela menimbulkan kecemasan pada keluarga.

\section{Tingkat Kecemasan Lansia Setelah}

\section{Diberikan Terapi SEFT}

Berdasarkan hasil penelitian menunjukan sebagian besar tingkat kecemasan lansia menghadapi masa pandemic covid-19 setelah diberikan terapi SEFT dengan kategori ringan yaitu sebanyak 53 responden $(67.1 \%)$, dan terendah adalah responden yang memiliki tingkat kecemasan sedang setelah diberikan terapi SEFT yaitu sebanyak 6 responden $(7.6 \%)$. Dari data tersebut dapat disimpulkan bahwa terjadi penurunan tingkat kecemasan dari skala sedang menjadi skala ringan setelah diberikan terapi SEFT. Hal ini disebabkan karena terapi SEFT dapat menimbulkan efek relaksasi dari ketukan ringan atau tapping pada pada titik-titik meridian di bagian tubuh. Teknik SEFT menyerupai teknik akupuntur dengan dikombinasikan dengan spiritualitas atau doa yang dipanjatkan dengan keihkalasan dan penuh kekhusyukan. Ketukan ringan yang diberikan merangsang sinyal-sinyal pada hipotalamus sehingga mengurangi hormon stress.

Hal tersebut didukung pendapat Church, (2009) SEFT digunakan stimulasi berupa ketukan ringan atau tapping pada titik acupoint. Pada saat tapping terjadi peningkatan proses perjalanan sinyalsinyal neurotransmitter yang menurunkan regulasi hipotalamic-pitutiary-adrenalAxis (HPA axis) sehingga mengurangi produksi hormon stres yaitu kortisol sehingga denyut jantung, tekanan darah tinggi, dan ketegangan otot menurun (Rohman, 2009).

Hasil penelitian ini didukung Chodijah, (2020) menjelaskan setelah pemberian terapi SEFT terhadap klien menunjukan bahwa dengan menggunakan tahapan yang tepat dari terapi SEFT, tingkat kecemasan klien menurun jauh, sehingga sehingga dapat dikatakan bahwa teknik SEFT dapat dijadikan sebagai salah satu teknik terapi yang tepat dan efektif dalam menangani klien yang mengalami kecemasan akibat mewabahnya virus covid-19.

\section{Pengaruh terapi spiritual emotional freedom technique (SEFT) terhadap penurunan tingkat kecemasan}

Hasil penelitian menunjukan adanya penurunan skala kecemasan antara sebelum dan sesudah lansia diberikan terapi SEFT dari tingkat kecemasan sedang menjadi kecemasan ringan. Setelah melalui 
uji nonparametrik Wilcoxon mendapatkan nilai $p=0.000$ ( $p$ value $<0,05)$, hal ini menunjukan adanya pengaruh terapi SEFT terhadap tingkat kecemasan pada lansia selama masa pandemic Covid-19 di Desa Grantung, Kecamatan Bayan, Kabupaten Purworejo nilai Z score 7.593> $\mathrm{Z}$ score table dimana $\mathrm{Z}$ table dengan tingkat alpha 0,05 adalah $-1,65$ yang berarti yang berarti ada perbedaan yang signifikan antara tingkat kecemasan lansia sebelum diberikan terapi SEFT dengan tingkat kecemasan lansia setelah diberikan terapi SEFT.

Efek tapping telah dibuktikan dengan sebuah penelitian di Harvard Medical School yang menunjukkan ketika seseorang yang dalam keadaan takut kemudian dilakukan tapping pada titik acupointnya maka terjadi penurunan akitivitas amygdala, dengan kata lain terjadi penurunan aktivitas gelombang otak sehingga kemudian memunculkan efek relaksasi yang akan menetralisir segala ketegangan emosi yang dialami individu. Efek ini sama dengan respon yang muncul ketika seseorang distimulasi dengan jarum akupuntur pada titik meridiannya (Feinsten \& Ashland, 2012).

Teknik tapping berfungsi untuk merangsang syaraf yang kaku, ketika tapping diberikan pada kecemasan maka mampu melenturkan (mengendorkan) syaraf-syaraf yang kaku. Tapping yang akan dilakukan terapis akan menghasilkan proses terapi energi dan EMDR (Eye
Dari proses tapping akan mengalami penurunan ketegangan. Ketukan-ketukan yang dilakukan oleh terapis, akan menambah energi subjek, setelah itu melakukan EMDR atau gerakan mata agar system syaraf otot merasa ringan atau tidak kaku.

Hasil penelitian ini didukung penelitian Hermansyah, (2017) menunjukan dari 32 lansia yang diteliti setelah dilakukan terapi SEFT sebagian responden mengalami tingkat kecemasan normal atau tidak ada kecemasan sebanyak 23 lansia $(71,9 \%)$. Sejalan dengan penelitian Yuswikarini (2011) menungkapkan dalam hasil penelitianya terapi spiritual emotional freedom technique efektif dalam menurunkan tingkat stress pada lansia penderita hipertensi. Analisa data menunjukan bahwa terjadi penurunan tingkat strees pada kelompok terapi dan kenaikan pada kelompok kontrol. Berbagai penelitian yang telah dilakukan di atas dapat ditarik kesimpulan bahwa penerapan SEFT efektif dapat digunakan untuk mengurangi tingkat kecemasan pada lansia.

\section{Kesimpulan}

Berdasarkan hasil analisa data dan pembahasan di atas dapat diambil kesimpulan sebagai berikut:

a. Karakateristik responden lansia di Desa Grantung, Kecamatan Bayan, Purworejo sebagian besar berumur 71-80 tahun, berjenis kelamin laki-laki dan memiliki tingkat pendidikan terakhir SD.

\section{Movement Densitization Repattering).}


b. Tingkat kecemasan lansia sebelum diberikan terapi SEFT sebagian besar dengan kategori kecemasan sedang

c. Tingkat kecemasan lansia setelah diberikan terapi SEFT sebagian besar dengan kategori ringan.

d. Ada pengaruh terapi SEFT terhadap tingkat kecemasan pada lansia selama masa pandemic Covid-19 di Desa Grantung dengan nilai $p=0.000$ ( $p$ value $<0,05)$.

\section{Ucapan Terima Kasih}

Dalam hal ini penulis mengucapkan terima kasih kepada Akper Pemkab Purworejo yang telah memberikan dukungan moril maupun materiil dalam penyelesaian publikasi ini.

\section{Daftar Pustaka}

Aufar A.F. (2020). Kegiatan Relaksasi Sebagai Coping Stress Di Masa Pandemi Covid19. Jurnal Kolaborasi Resolusi Konflik Volume 2 Nomor 2. Halaman 157-163.

Brahmantia, Bayu., Huriah,T. (2018). Pengaruh Spiritual Emotional Freedom Technique (SEFT) Terhadap Penurunan Nyeri Dan Kecemasan Pada Pasien Pasca Bedah Transurethral Resection Prostate (TURP) di RSUD dr. Soekardjo Kota Tasikmalaya. Jurnal Kesehatan Karya Husada, Vol.6, No. 2 Tahun 2018.

Chodijah, M., Nurjannah, D, S. A., Yuliyanti, Y. \& Kamba, M, N, S. (2020). SEFT sebagai terapi mengatasi kecemasan menghadapi covid-19. Tasawuf Psikoterapi, Universitas Gunung Djati Bandung.

Direktorat Pencegahan Dan Pengendalian Penyakit Tidak Menular. (2018). Teknik relaksasi untuk mengatasi stres.
Retrieved from Kementerian Kesehatan Republik Indonesia: http://p2ptm.kemkes.go.id/infographicp2 $\mathrm{ptm} / \mathrm{stress} /$ teknik-relaksasiuntukmengatasi-stres

Fricchione, G. L., Joos, S., \& Teut, M. (2013). Self-care, stress management, and primary care: From salutogenesis and health promotion to mind-body medicine. Evidence-based Complementary and Alternative Medicine (Vol. 2013).

Fitria, L \& Ifdil, I. (2020). Kecemasan remaja pada masa pandemi Covid -19. Jurnal Educatio (Jurnal Pendidikan Indonesia. Vol. 6, No. 1, 2020, pp. 1-4).

Hawari, D. (2011). Manajemen Stres, Cemas, dan Depresi. Jakarta: Balai Penerbit FKUI

Herman Syah, Bayu. (2017). Terapi spiritual emotional freedom technique (SEFT) untuk mengurangi kecemasan pada lanjut usia. Skripsi. Sekolah Tinggi Ilmu Kesehatan "Insan Cendekia Medika" Jombang.

Huang, Y., \& Zhao, N. (2020). Generalized anxiety disorder, depressive symptoms and sleep quality during COVID-19 outbreak in China: a web-based cross-sectional survey. Psychiatry Research, 288(March), 112954.https://doi.org/10.1016/j.psychres .2020

Kemnterian Kesehatan RI. 2020. CoVID-19 dalam Angka. Kondisi 22 Agustus 2020.https://www.kemkes.go.id/resource s/download/infoterkini/covid\%20dalam\% 20angka/covid-19-dalam-angka-22agustus-2020.pdf

Setiyani, H, Ayu, S.M. (2019). Hubungan Tingkat Pendidikan, Pendapatan Dan Dukungan Keluarga Dengan Kecemasan Pada Wanita Menopause Di Desa Jobohan, Bokoharjo, Sleman 2016. Jurnal Medika Respati Vol. 14 No 2 April 2019. 
Stuart, GW. (2012). Buku saku keperawatan jiwa, Edsisi 5. Jakarta: EGC

Zainuddin, A. F. (2012). SEFT Total Solution. Jakarta : SEFT Corporation.

WHO. (2020). Prevalensi Corona Virus Disease di Dunia. WHO: Geneva. 